\title{
AKRUAL
}

Jurnal Akuntansi

http://fe.unesa.ac.id/ojs/index.php/akrl

\section{ANALISIS PERBANDINGAN KINERJA KEUANGAN SEBELUM DAN SESUDAH MERGER DENGAN MENGGUNAKAN METODE ECONOMIC VALUE ADDED (EVA) DAN MARKET VALUE ADDED (MVA) PADA PT UNILEVER INDONESIA TBK}

\author{
Rakhmi Ayu Zulvina \\ Musdholifah \\ Universitas Negeri Surabaya \\ E-mail: musdholifah@yahoo.com. \\ Artikel diterima: 25 Januari 2010 \\ Revisi terakhir: 1 Maret 2010
}

\begin{abstract}
Merger is a decision to combine or merge two or more companies into one new company. One of the merged company in Indonesia is PT Unilever Indonesia Tbk with PT Knorr Indonesia in 2004. To identify and analyze it, EVA and MVA method is used, then the results of the calculations tested using normality test statistical tool kolmogorov smirnov, and carried out by means of differential test paired samples T-test.The increase of EVA before and after the merger worth $125.30 \%$. While the increase in MVA before and after the merger worth $227.33 \%$. Increasing the value of MVA was more due to the company's market value, which is reflected in the share price and listed share, although not free from invested capital in the company
\end{abstract}

Keywords: financial performance, merger, EVA, MVA

\section{PENDAHULUAN}

\section{Latar Belakang}

Globalisasi dan persaingan bebas menuntut setiap perusahaan untuk selalu mengembangkan strateginya agar dapat bertahan, berkembang dan berdaya saing. Untuk itu perusahaan perlu menyusun atau membuat strategi yang tidak hanya bertujuan untuk bertahan ditengah persaingan usaha, tetapi juga agar dapat terus berkembang. Diperlukan suatu strategi yang tepat untuk tetap bertahan dan terus meningkatkan kinerja perusahaan.

Salah satu strategi yang dapat ditempuh perusahaan adalah dengan melakukan ekspansi (perluasan usaha), baik dalam bentuk ekspansi internal maupun ekspansi eksternal (Muhammad dalam Hadiningsih, 2007:1). Ekspansi internal terjadi pada saat divisi-divisi yang ada dalam perusahaan tumbuh secara normal melalui kegiatan capital budgeting, seperti menambah kapasitas pabrik, menambah unit produksi, dan menambah divisi baru. Ekspansi eksternal dapat dilakukan dengan penggabungan usaha-usaha yang ada (merger dan konsolidasi), atau dengan membeli perusahaan (akuisisi) (Husnan dan Pudjiastuti, 2004:391). 
Menurut Moin (2007:308), setelah dilakukan merger, kinerja keuangan perusahaan setelah merger seharusnya semakin baik dibandingkan dengan sebelum merger. Untuk mengetahui kondisi keuangan perusahaan tersebut, diperlukan penilaian terhadap kinerja perusahaan. Dengan adanya penilaian kinerja keuangan dapat diketahui apakah prestasi yang dicapai perusahaan telah memenuhi harapan dari pihak-pihak yang terlibat, terutama dalam perencanaan investasi yang akan dilakukan investor.

Merger, konsolidasi, maupun akuisisi ditempuh oleh perusahaan-perusahaan besar guna meningkatkan efisiensi dan kinerja perusahaan dan selanjutnya diharapkan dapat meningkatkan profitabilitas. Kegiatan merger dan akuisisi mulai mewarnai industri pasar modal Indonesia pada tahun 1990, dengan transaksi penggabungan pertama yang dilakukan oleh PT. Jakarta International Hotel Development melalui pembelian 100\% saham PT. Danayasa Arthatama. Majalah SWA dalam Fisnia (2009:8), menyatakan bahwa perusahaan yang melakukan merger dan akuisisi mendapatkan keuntungan, contohnya PT. Asuransi Jiwa Manulife Indonesia (AJMI) yang mengakuisisi PT. Prinsipal Indonesia yang kemudian menaikkan asetnya dari RP. 2,1 Triliun menjadi Rp. 2,4 Triliun. Keuntungan dan keberhasilan perusahaan-perusahaan yang melakukan merger juga ditunjukkan oleh penelitian Poposki (2007) yang berjudul "merger activity in the insurance industry", yang menyatakan bahwa Merger dan akuisisi di industri asuransi Eropa sebagian besar didorong oleh tujuan-tujuan ekonomi dan mempunyai efek menguntungkan pada efisiensi dalam industri asuransi.

Pada kenyataannya perusahaan-perusahaan yang melakukan merger tidak selalu mendapatkan manfaat. Misalnya adalah Hewlett-Packard, Co. (HP) yang melakukan merger dengan Compact dengan tujuan untuk mengukuhkan posisi HP, agar lebih baik dibandingkan IBM dan Dell. Seharusnya merger dua perusahaan dengan keunggulan berbeda tersebut bisa menimbulkan sinergi, namun pada kenyataannya tidak demikian. Kinerja HP tidak menentu, harga sahamnya naik turun (Fisnia 2009:9). Salah satu penelitian yang mendukung pernyataan ini adalah penelitian yang dilakukan oleh Samosir pada tahun 2003, yang berjudul "Analisis kinerja Bank Mandiri setelah merger dan sebagai Bank rekapitalisasi". Hasil penelitian tersebut menunjukkan bahwa tidak ada perbedaan antara kinerja keuangan Bank mandiri sebelum merger hingga tiga tahun sesudah merger. Sebelum merger Bank Mandiri merupakan bank yang tidak sehat yang diketahui melalui nilai ROA, ROE, DER dan DTARnya. Merger tidak memberikan pengaruh yang positif terhadap kondisi keuangan Bank Mandiri.

Fenomena yang bertentangan tersebut menunjukkan bahwa dalam melakukan merger, perusahaan harus mempertimbangkan keuntungan maupun kerugian yang mungkin terjadi. Walaupun demikian, strategi penggabungan usaha menjadi salah satu pilihan menarik yang dapat diambil oleh perusahaan. Salah satu perusahaan yang melakukan merger di Indonesia adalah PT Knorr Indonesia yang bergabung kepada PT. Unilever Indonesia Tbk pada 30 Juli 2004. PT. Unilever Indonesia Tbk bergerak dalam bidang produksi sabun, deterjen, margarin, minyak sayur dan makanan yang terbuat dari susu, es krim, makanan dan minuman dari teh dan produk-produk kosmetik, sedangkan PT. Knorr Indonesia merupakan produsen bumbu makanan, saus, selai, minuman, dan makanan kemasan cepat saji. Merger 
ini merupakan kelanjutan akuisisi Unilever terhadap 99,99 persen saham PT Knorr Indonesia yang dilakukan sebelumnya, yaitu pada 21 Januari 2004.

Metode yang paling sering digunakan untuk mengukur kinerja keuangan adalah rasio keuangan (financial ratio), yang dianalisis dari laporan keuangan perusahaan. Namun metode financial ratio ini memiliki kelemahan, diantaranya yaitu kinerja dan prestasi manajemen yang diukur dengan rasio-rasio keuangan tidak dapat dipertanggungjawabkan karena rasio keuangan yang dihasilkan didasarkan pada angka akuntansi, serta metodologinya pada dasarnya bersifat parsial, yang artinya setiap rasio diuji secara terpisah. Selain itu kelemahan lain didalam perhitungan dengan metode laba akuntansi adalah mengabaikan cost of equity, dan hanya mempertimbangkan cost of debt (Campaka, 2009:2).

Untuk menyempurnakan penilaian kinerja keuangan dengan menggunakan metode financial ratio, muncul suatu metode pengukuran kinerja keuangan yang mengukur laba ekonomi dalam suatu perusahaan yang menyatakan bahwa kesejahteraan hanya dapat tercipta manakala perusahaan mampu memenuhi semua biaya operasi dan biaya modal, yaitu EVA. EVA adalah laba bersih operasional sebelum bunga tetapi setelah pajak (NOPAT), dikurangi biaya modal berdasarkan WACC dikali invested capital (Wet dan Hall, 2004:42).

Alat ukur kinerja keuangan yang relatif baru jika dibandingkan dengan financial ratio selain EVA adalah market value added (MVA). Dari sudut pandang investor, MVA adalah ukuran akhir terbaik untuk menilai kinerja perusahaan (Wet dan Hall, 2004:41). MVA adalah nilai yang diperoleh pemegang saham, atau dengan kata lain MVA adalah kekayaan yang dapat diciptakan perusahaan untuk pemegang saham (Young dan O'Byrne, 2001:27-28).

Berdasarkan uraian-uraian di atas, peneliti ingin mengetahui apakah merger yang dilakukan oleh PT. Unilever Indonesia Tbk dengan PT. Knorr Indonesia akan meningkatkan kinerja keuangan PT. Unilever Indonesia, Tbk. Penilaian kinerja dilakukan dengan menggunakan metode EVA dan MVA. Merger kedua perusahaan ini dilakukan pada tahun 2004. Penelitian dilakukan pada empat tahun sebelum dan empat tahun sesudah merger, yaitu pada tahun 2000-2003 dan 20052008, dimana tahun 2004 merupakan tahun netral, karena pada tahun ini kedua perusahaan baru bergabung dan melebur menjadi satu, yaitu PT. Unilever Indonesia. Dengan demikian, peneliti bermaksud untuk melakukan penelitian dengan judul "Analisis perbandingan kinerja keuangan sebelum dan sesudah merger dengan menggunakan metode Economic Value Added (EVA) dan Market Value Added (MVA) pada PT. Unilever Indonesia Tbk".

\section{Rumusan Masalah}

1. Apakah terdapat perbedaan kinerja keuangan sebelum dan sesudah merger dengan menggunakan metode Economic value added (EVA) pada PT. Unilever Indonesia Tbk?

2. Apakah terdapat perbedaan kinerja keuangan sebelum dan sesudah merger dengan menggunakan metode Market value added (MVA) pada PT. Unilever Indonesia Tbk? 


\section{Tujuan Penelitian}

1. Untuk mengetahui dan menganalisis perbedaan kinerja keuangan sebelum dan sesudah merger dengan menggunakan metode EVA pada PT. Unilever Indonesia Tbk.

2. Untuk mengetahui dan menganalisis perbedaan kinerja keuangan sebelum dan sesudah merger dengan menggunakan metode MVA pada PT. Unilever Indonesia Tbk

\section{KAJIAN PUSTAKA}

Merger adalah penggabungan dua atau lebih perusahaan yang kemudian hanya ada satu perusahaan yang tetap hidup sebagai badan hukum, sementara yang lainnya menghentikan aktivitasnya atau bubar (Moin, 2007:5). Pada prinsipnya terdapat dua motif yang mendorong sebuah perusahaan melakukan merger dan akuisisi yaitu motif ekonomi dan motif non-ekonomi. Motif ekonomi berkaitan dengan esensi tujuan perusahaan yaitu meningkatkan nilai perusahaan atau memaksimumkan kemakmuran pemegang saham. Di sisi lain, motif non ekonomi adalah motif yang bukan didasarkan pada esensi tujuan perusahaan tersebut, tetapi didasarkan pada keinginan subyektif atau ambisi pribadi pemilik atau manajemen perusahaan (Moin, 2007:53-62).

Tujuan umum perusahaan melakukan merger dengan perusahaan lain antara lain untuk meningkatkan pangsa pasar dan nilai tambah melalui upaya penciptaan efisiensi yang lebih baik, meningkatkan sinergi operasional, sinergi keuangan, strategic realignment (Samosir, 2003:11-12).

Menurut Moin (2007:308), setelah dilakukan merger, ukuran perusahaan akan bertambah besar karena aset, kewajiban dan ekuitas perusahaan digabung bersama. Dengan bertambahnya ukuran dan ditambah dengan sinergi yang dihasilkan dari gabungan aktivitas-aktivitas simultan, maka secara logis laba perusahaan juga akan meningkat. Oleh karena itu kinerja keuangan perusahaan setelah merger seharusnya semakin baik dibandingkan dengan sebelum merger. Untuk mengetahui kondisi keuangan perusahaan tersebut, diperlukan penilaian terhadap kinerja perusahaan. Dengan adanya penilaian kinerja keuangan dapat diketahui apakah prestasi yang dicapai perusahaan telah memenuhi harapan dari pihak-pihak yang terlibat, terutama dalam perencanaan investasi yang akan dilakukan investor.

Pada umumnya tujuan dilakukannya merger dan akuisisi adalah mendapatkan sinergi atau nilai tambah. Nilai tambah yang dimaksud tersebut lebih bersifat jangka panjang dibanding dengan nilai tambah yang bersifat sementara saja. Oleh karena itu, ada tidaknya sinergi suatu akuisisi dan merger tidak bisa dilihat beberapa saat setelah merger dan akuisisi terjadi, tetapi diperlukan waktu yang relatif panjang. Sinergi yang terjadi sebagai akibat penggabungan usaha berupa turunnya biaya rata-rata perunit karena naiknya skala ekonomi, maupun sinergi keuangan yang berupa kenaikan modal. Sinergi yang diperoleh juga dapat berupa keunggulan cost yang semakin rendah, akses terhadap sumber daya yang semakin baik, dengan demikian kinerja dan efisiensi perusahaan yang bergabung akan meningkat.

Kinerja keuangan adalah penentuan secara periodik efektivitas operasional suatu organisasi, bagian organisasi dan karyawannya berdasarkan sasaran, standar 
dan kriteria yang ditentukan sebelumnya (Mulyadi, 2001:415-416). Tujuan pokok penilaian kinerja keuangan perusahaan menurut Mulyadi (2001:416) adalah untuk memotivasi karyawan dalam mencapai sasaran organisasi dan memenuhi standar perilaku yang telah ditetapkan sebelumnya, agar membuahkan tindakan dan hasil yang diinginkan.

Salah satu alat ukur kinerja yang mengukur nilai tambah adalah EVA. EVA pertama kali dikembangkan oleh Stewart \& Stern seorang analis keuangan dari perusahaan Stern Stewart \& Co pada tahun 1993. Di Indonesia metode tersebut dikenal dengan metode NITAMI (Nilai Tambah Ekonomi). EVA/NITAMI adalah metode manajemen keuangan untuk mengukur laba ekonomi dalam suatu perusahaan yang menyatakan bahwa kesejahteraan hanya dapat tercipta manakala perusahaan mampu memenuhi semua biaya operasi dan biaya modal (Tunggal, 2001).

EVA adalah laba bersih operasional sebelum bunga tetapi setelah pajak (NOPAT), dikurangi biaya modal berdasarkan WACC dikali invested capital (Wet dan Hall, 2004:42). Dengan demikian, EVA merupakan kemampuan perusahaan untuk mendapatkan pengembalian atas biaya modal (Wet dan Hall, 2004:39). Sedangkan menurut Utomo (1999:29), EVA adalah ukuran nilai tambah ekonomi yang dihasilkan oleh perusahaan sebagai akibat dari aktivitas atau strategi manajemen. EVA baik digunakan untuk tujuan pengambilan keputusan dan untuk mengukur prestasi (Zafiris dan Bayldon, 1999:84). EVA merupakan tujuan perusahaan untuk meningkatkan nilai atau value added dari modal yang telah ditanamkan pemegang saham dalam operasi perusahaan (Iramani dan Febrian, 2005:3). Berikut ini adalah beberapa tahap perhitungan EVA:

1. Menghitung NOPAT (Net Operating Profit After Taxes)

NOPAT merupakan laba operasi perusahaan, setelah pajak, dan mengukur laba yang diperoleh perusahaan dari operasi berjalan. Menurut Brigham dan Houston (2006:69), NOPAT dapat dihitung dengan menggunakan rumus sebagai berikut:

NOPAT $=$ EBIT $(1-t)$

2. Menghitung biaya modal (cost of capital)

Cost of capital adalah tingkat pengembalian minimum yang diharapkan oleh pemegang saham (pemilik) perusahaan dalam investasinya (Utomo, 1999:37). Pada umumnya komponen cost of capital terdiri dari biaya modal hutang (cost of debt) dan biaya modal saham (cost of equity).

a. Cost of debt adalah tingkat pengembalian yang dikehendaki karena adanya resiko kredit (credit risk), yaitu resiko perusahaan dalam memenuhi kewajiban pembayaran bunga dan pokok hutang. Dengan kata lain, cost of debt adalah tarif yang dibayar perusahaan untuk memperoleh tambahan hutang baru jangka panjang di pasar sekarang (Utomo, 1999:38).

b. Cost of equity adalah tingkat pengembalian yang dikehendaki investor karena adanya ketidakpastian tingkat laba (Utomo, 1999:37). Biaya modal saham merupakan tingkat hasil pengembalian atas saham biasa yang diinginkan oleh para investor (Iramani dan Febrian, 2005:5). Biaya modal saham biasa didapatkan dengan menggunakan Model penentuan harga aktiva modal (capital asset pricing model - CAPM), dengan menggunakan rumus (Iramani dan Febrian, 2005:5-6): 
$\mathrm{ks}=\mathrm{Rf}+(\mathrm{Rm}-\mathrm{Rf}) \beta$

Dimana:

$\mathrm{ks}=$ tingkat pengembalian yang diinginkan investor (opportunity of equity)

$\mathrm{Rf}=$ tingkat bunga investasi yang diperoleh tanpa resiko (risk free)

$\mathrm{Rm}=$ tingkat bunga investasi rata - rata dari pasar

$\beta=$ ukuran resiko saham perusahaan

3. Menghitung biaya modal rata-rata tertimbang (Weight Average Cost of Capital-WACC)

Weston dan Brigham (1990:116) menyatakan bahwa biaya modal rata-rata tertimbang terdiri dari komponen biaya hutang, saham preferen dan ekuitas biasa. Dalam perhitungan WACC digunakan bentuk struktur modal yang mengacu pada proporsi dari masing-masing sumber keuangan yang digunakan oleh perusahaan.

Dalam praktek, pembiayaan/pendanaan yang digunakan perusahaan diperoleh dari berbagai sumber. Dengan demikian biaya riil yang ditanggung oleh perusahaan merupakan keseluruhan biaya untuk semua sumber pembiayaan yang digunakan, dimana perhitungannya dapat menggunakan rumus berikut (Iramani dan Febrian, 2005:6):

$$
\mathrm{WACC}=\mathrm{Wd} . \mathrm{kd}(1-\mathrm{t})+\mathrm{Ws} . \mathrm{Ks}
$$

\section{Dimana:}

WACC $=$ Biaya modal rata - rata tertimbang

$\mathrm{Wd}=$ Proporsi hutang jangka panjang dalam struktur modal

$\mathrm{Kd}=$ Cost of debt sebelum pajak

$\mathrm{Ws}=$ Proporsi saham dalam struktur modal

$\mathrm{Ks}=$ Tingkat pengembalian yang diinginkan investor

$\mathrm{t}=$ Pajak

4. $\quad$ Menghitung invested capital

Modal yang diinvestasikan adalah jumlah seluruh keuangan perusahaan terlepas dari kewajiban jangka pendek, pasiva yang tidak menanggung bunga, seperti hutang, upah yang akan jatuh tempo, dan pajak yang akan jatuh tempo. Modal yang diinvestasikan sama dengan jumlah ekuitas pemegang saham, seluruh hutang jangka pendek dan jangka panjang yang menanggung bunga, hutang, dan kewajiban jangka panjang lainnya.

\section{Menghitung capital charges}

Capital charges merupakan WACC dikalikan invested capital (Wet dan Hall, 2004:42). Capital charges merupakan aspek paling penting dan khas dalam EVA. Didalamnya memperhitungkan biaya-biaya yang seharusnya dibayarkan ke pemegang saham dan biaya-biaya yang harus dibayarkan kepada kreditur dalam bentuk bunga, yang selama ini tidak tercermin dalam laporan akuntansi.

6. Menghitung EVA 
EVA dapat didefinisikan sebagai laba bersih operasional sebelum bunga, tetapi setelah pajak (NOPAT), dikurangi dengan biaya modal berdasarkan WACC dikalikan dengan Invested Capital (Wet dan Hall, 2004:42).

$$
\begin{aligned}
& \mathrm{EVA}=\mathrm{NOPAT}-(\text { WACC } \mathrm{x} \text { Invested } \text { Capital }) \\
& \mathrm{EVA}=\mathrm{NOPAT}-\text { Capital charges }
\end{aligned}
$$

Dari perhitungan akan diperoleh kesimpulan dengan interprestasi hasil sebagai berikut (Iramani dan febrian, 2005:4):

1. Jika EVA > 0 hal ini menunjukkan terjadi nilai tambah ekonomis bagi perusahaan.

2. Jika EVA < 0 hal ini menunjukkan tidak terjadi nilai tambah ekonomis bagi perusahaan.

3. Jika EVA $=0$ hal ini menunjukkan posisi impas karena laba telah digunakan untuk membayar kewajiban kepada penyandang dana baik kreditur maupun pemegang saham.

Salah satu keunggulan EVA (Iramani dan Febrian, 2005:6) sebagai penilai kinerja perusahaan adalah dapat digunakan sebagai penciptaan nilai (value creation). Keunggulan EVA yang lain adalah:

1. EVA memfokuskan penilaian pada nilai tambah dengan memperhitungan beban sebagai konsekuensi investasi.

2. Konsep EVA adalah alat perusahaan dalam mengukur harapan yang dilihat dari segi ekonomis dalam pengukurannya yaitu dengan memperhatikan harapan para penyandang dana secara adil dimana derajat keadilan dinyatakan dengan ukuran tertimbang dari struktur modal yang ada dan berpedoman pada nilai pasar dan bukan pada nilai buku.

3. Perhitungan EVA dapat dipergunakan secara mandiri tanpa memerlukan data pembanding seperti standar industri atau data perusahaan lain sebagai konsep penilaian.

4. Konsep EVA dapat digunakan sebagai dasar penilaian pemberian bonus pada karyawan terutama pada divisi yang memberikan EVA lebih sehingga dapat dikatakan bahwa EVA menjalankan stakeholders satisfaction concepts.

5. Pengaplikasian EVA yang mudah menunjukkan bahwa konsep tersebut merupakan ukuran praktis, mudah dihitung dan mudah digunakan sehingga merupakan salah satu bahan pertimbangan dalam mempercepat pengambilan keputusan bisnis.

Selain berbagai keunggulan, konsep EVA juga memiliki kelemahankelemahan. Menurut Iramani dan Febrian (2005:6), kelemahan-kelemahan tersebut antara lain :

1. EVA hanya mengukur hasil akhir (result), konsep ini tidak mengukur aktivitas-aktivitas penentu.

2. EVA terlalu bertumpu pada keyakinan bahwa investor sangat mengandalkan pendekatan fundamental dalam mengkaji dan mengambil keputusan untuk menjual atau membeli saham tertentu padahal faktor-faktor lain terkadang justru lebih dominan.

Selain EVA, alat ukur kinerja yang juga bertumpu pada penciptaan nilai adalah MVA. MVA adalah nilai yang diperoleh pemegang saham, atau dengan 
kata lain MVA adalah kekayaan yang dapat diciptakan perusahaan untuk pemegang saham (Young dan O'Byrne, 2001). MVA dapat dihitung dengan menggunakan rumus:

MVA = nilai pasar saham - modal yang diinvestasikan

$=$ (jumlah saham beredar)(harga saham)-modal yang diinvestasikan

MVA merupakan present value dari EVA, dimana setara dengan present value arus kas yang relevan untuk penilaian investasi. MVA adalah sama dengan nilai sekarang dari semua nilai EVA dimasa depan. Dengan asumsi bahwa tidak akan ada pertumbuhan dimasa yang akan datang dari nilai EVA sekarang, atau bahwa pertumbuhan EVA berada pada laju konstan (Wet dan Hall, 2004:44).

MVA yang positif menandakan perusahaan berhasil menciptakan nilai bagi pasar dan pemilik modal karena perusahaan dapat menghasilkan tingkat pengembalian yang melebihi tingkat biaya modalnya. Hal ini sejalan dengan tujuan perusahaan yaitu memaksimalkan nilai perusahaan. Semakin besar MVA, semakin baik (Young dan O'Byrne, 2001:27). Semakin tinggi MVA, semakin baik pekerjaan yang telah dilakukan oleh para manajer bagi pemegang saham perusahaan (Brigham dan Houston, 2006:68).

Viverita dalam penelitiannya menyatakan bahwa Merger tidak meningkatkan kemampuan bank untuk mendapatkan keuntungan jika dilihat dari ROA, laba atas ekuitas, net interest margin, rasio kecukupan modal dan non-performing loans. Meger juga tidak dapat meningkatkan kemampuan bank untuk melaksanakan fungsi sebagai lembaga perantara, ditunjukkan oleh penurunan rasio pinjaman untuk deposito yang dikumpulkan dari nasabah. Merger dapat meningkatkan efisiensi operasi secara optimal.

Dalam penelitiannya, Samosir menyatakan bahwa dari Return on assets, Return on equity, Debt to equity ratio, dan Debt to total assets ratio menunjukkan bahwa kondisi bank Mandiri sebelum merger tidak sehat, dan hingga tiga tahun setelah merger keadaan tersebut belum berubah. Sehingga dapat disimpulkan bahwa kinerja keuangan Bank mandiri setelah merger tidak mengalami peningkatan, dimana salah satunya disebabkan oleh kondisi Bank Exim, Bank Dagang negara, Bank Bumi Daya dan Bank Pembangunan Indonesia sebelum bergabung menjadi Bank Mandiri dalam keadaan yang tidak sehat.

Sedangkan Penelitian Fisnia (2009) yang menyatakan bahwa dari dua tahun sebelum dan dua tahun sesudah merger, nilai EVA pada masing-masing perusahaan sampel, mayoritas bernilai positif. Dan sebagian besar perusahaan sampel mengalami peningkatan EVA sesudah merger. Hasil tersebut menunjukkan bahwa sebagian besar merger membawa sinergi dan nilai tambah (value firm) bagi perusahaan.

Penelitian Poposki menyatakan bahwa dari rasio solvabilitas, likuiditas, underwriting leverage dan cadangan leverage diketahui merger dan akuisisi di industri asuransi di Eropa sebagian besar didorong oleh tujuan-tujuan ekonomis dan mempunyai efek menguntungkan pada efisiensi dalam industri. Merger yang dilakukan di Industri asuransi di Eropa memberikan efek menguntungkan pada efisiensi dalam industri karena dari beberapa rasio yang disebutkan diatas diketahui bahwa merger yang dilakukan tercipta suatu sinergi keuangan. Hipotesis yang diajukan dalam penelitian ini adalah: 
H1: Diduga terdapat perbedaan kinerja keuangan sebelum dan sesudah merger dengan menggunakan metode EVA pada PT. Unilever Indonesia Tbk.

$\mathrm{H} 2$ : Diduga terdapat perbedaan kinerja keuangan sebelum dan sesudah merger dengan menggunakan metode MVA pada PT. Unilever Indonesia Tbk.

\section{METODE PENELITIAN}

\section{Jenis Penelitian}

Jenis penelitian ini adalah penelitian studi peristiwa (event study), yaitu studi yang mempelajari reaksi pasar terhadap suatu peristiwa (event) atas adanya informasi yang dipublikasikan sebagai suatu pengumuman. Event (peristiwa) yang terjadi adalah merger, antara PT. Unilever Indonesia Tbk dengan PT. Knorr Indonesia yang dilakukan pada tahun 2004. Periode pengamatan dalam penelitian ini adalah tahun 2000-2003 dan tahun 2005-2008. Pendekatan yang digunakan dalam penelitian ini adalah pendekatan kuantitatif, yaitu pendekatan berdasarkan data yang berbentuk angka (Sugiyono, 2005:13).

\section{Definisi Operasional}

EVA adalah laba bersih operasional sebelum bunga tetapi setelah pajak (NOPAT), dikurangi biaya modal berdasarkan WACC dikali invested capital (Wet dan Hall, 2004:42). Langkah-langkah perhitungan untuk menentukan EVA adalah sebagai berikut:

1. Menghitung NOPAT (Net Operating Profit After Tax)

Menurut Brigham dan Houston (2006:69), NOPAT dapat dihitung dengan menggunakan rumus sebagai berikut:

NOPAT $=$ EBIT $(1-t)$

2. Menghitung biaya modal (cost of capital)

Pada umumnya komponen cost of capital terdiri dari biaya modal hutang (cost of debt) dan biaya modal saham (cost of equity).

a. Cost of Debt

Cost of debt dapat dihitung dengan rumus (Iramani dan Febrian, 2005:5):

Biaya hutang setelah pajak $=\mathrm{kd}^{*}=\mathrm{kd}(1-\mathrm{t})$

$$
\mathrm{Kd}=\frac{\text { BebanBunga }}{\text { Hu tan gJangkaPanjang }}
$$

Dimana :

$\mathrm{kd}^{*}$ : biaya hutang setelah pajak

$\mathrm{kd}$ : biaya hutang sebelum pajak

$\mathrm{t}:$ tarif pajak

b. Cost of equity

Biaya modal saham biasa didapatkan dengan menggunakan Model penentuan harga aktiva modal (capital asset pricing model - CAPM), dengan mengunakan rumus (Iramani dan Febrian, 2005:5-6): 
$\mathrm{ks}=\mathrm{Rf}+(\mathrm{Rm}-\mathrm{Rf}) \beta$

Dimana:

$\mathrm{ks}$ = tingkat pengembalian yang diinginkan investor (opportunity of equity)

$\mathrm{Rf}=$ tingkat bunga investasi yang diperoleh tanpa resiko (risk free)

$\mathrm{Rm}=$ tingkat bunga investasi rata - rata dari pasar

$\mathrm{B}=$ ukuran resiko saham perusahaan

Selanjutnya langkah perhitungan biaya modal saham dengan CAPM dilakukan dengan langkah sebagai berikut:

1. Menghitung suku bunga bebas resiko.

Tingkat suku bunga bebas resiko diperoleh dari perhitungan rata-rata suku bunga Sertifikat Bank Indonesia (SBI) selama satu tahun. Dihitung selama tahun 2000-2003 dan tahun 2005-2008.

2. Menghitung tingkat Return Market (Rm).

Menurut Moin (2007:301), Return Market dapat dihitung sebagai berikut:

$\mathrm{R}_{\mathrm{m}}=\frac{I H S G_{t}-I H S G_{t-1}}{I H S G_{t-1}}$

Dimana:

$\mathrm{Rm}=$ Tingkat keuntungan rata-rata pasar .

$\mathrm{IHSG}_{\mathrm{t}}=\mathrm{IHSG}$ periode $\mathrm{t}$.

$\mathrm{IHSG}_{\mathrm{t}-1}=\mathrm{IHSG}$ periode $\mathrm{t}-1$.

3. Menghitung tingkat return saham individual (Ri)

Menurut Jogiyanto (2003:111), Ri dapat dihitung dengan menggunakan rumus sebagai berikut:

$\mathrm{Ri}=\frac{p_{t}-p_{t-1}}{p_{t-1}}+\frac{D_{t}}{p_{t-1}}$

Dimana :

$\mathrm{Ri}=$ Return saham individual

$\mathrm{P}_{\mathrm{t}}=$ Harga saham periode $\mathrm{t}$

$\mathrm{P}_{\mathrm{t}-1}=$ Harga saham $\mathrm{t}-1$

$\mathrm{D}_{\mathrm{t}}=$ Deviden yang dibayarkan pada periode $\mathrm{t}$.

4. Menghitung koefisien beta $(\beta)$

Untuk menghitung beta dapat dilakukan dengan mengunakan pendekatan regresi (Husnan, 1998:115) :

$\beta=\frac{n \sum x y-\sum x \sum y}{n \sum x^{2}-\left(\sum x\right)^{2}}$ 
Dimana :

$\mathrm{n}=$ jumlah observasi

$\mathrm{x}=$ tingkat keuntungan portofolio pasar $\left(\mathrm{R}_{\mathrm{m}}\right)$

$\mathrm{y}=$ tingkat keuntungan saham $\left(\mathrm{R}_{\mathrm{i}}\right)$

3. Menghitung biaya modal rata-rata tertimbang (Weight Average Cost of Capital-WACC)

Dalam praktek, pembiayaan atau pendanaan yang digunakan perusahaan diperoleh dari berbagai sumber. Dengan demikian biaya riil yang ditanggung oleh perusahaan merupakan keseluruhan biaya untuk semua sumber pembiayaan yang digunakan, dimana perhitungannya dapat menggunakan rumus berikut (Weston dan Copeland dalam Iramani dan Febrian, 2005:6):

$\mathrm{WACC}=\mathrm{Wd} . \mathrm{Kd}(1-\mathrm{t})+\mathrm{Ws} . \mathrm{Ks}$

$\mathrm{Wd}=\frac{\text { Hutang Jangka Panjang }}{\text { Total modal }} \quad \mathrm{x} \quad$ Total modal Saham

$\mathrm{Ws}=\quad$ Total Modal Saham

Total modal

Dimana:

WACC $=$ Biaya modal rata - rata tertimbang

$\mathrm{Wd}=$ Proporsi hutang jangka panjang dalam struktur modal

$\mathrm{Kd}=$ Cost of debt sebelum pajak

Ws $=$ Proporsi saham biasa dalam struktur modal

$\mathrm{ks}=$ Tingkat pengembalian yang diinginkan investor

$\mathrm{t}=$ Pajak

4. Invested Capital

Invested Capital dapat dihitung dengan rumus:

Hutang jangka pendek dengan bunga + hutang jangka panjang + ekuitas pemegang saham + Hak minoritas. (Young dan O'Byrne, 2001:39).

5. Capital Charges

Capital charges merupakan WACC dikalikan invested capital (Wet dan Hall, 2004:42).

6. Menghitung EVA

Menurut Wet and Hall (2004:42), EVA dapat dihitung dengan menggunakan rumus:

$\mathrm{EVA}=\mathrm{NOPAT}-(\mathrm{WACC} \times \mathrm{x}$ Invested Capital $)$

$\mathrm{EVA}=\mathrm{NOPAT}-$ Capital charges . 
Dimana :

NOPAT $=$ Net Operating Profit After Taxes

WACC $=$ Weighted Average Cost of Capital

Selain dapat diukur dengan menggunakan metode EVA, kinerja keuangan dalam penelitian ini juga diukur dengan menggunakan metode MVA. Dari sudut pandang investor, MVA adalah ukuran akhir terbaik untuk menilai kinerja perusahaan (Wet dan Hall, 2004:41). Untuk memaksimalkan nilai bagi pemegang saham, perusahaan harus berusaha untuk memaksimalkan MVA. MVA adalah nilai yang diperoleh pemegang saham, atau dengan kata lain MVA adalah kekayaan yang dapat diciptakan perusahaan untuk pemegang saham (Young dan O’Byrne, 2001). MVA dapat dihitung dengan menggunakan rumus:

MVA $=$ nilai pasar saham - modal yang diinvestasikan

$=$ (jumlah saham beredar)(harga saham)-modal yang diinvestasikan

\section{Populasi dan Sampel.}

Populasi adalah keseluruhan subjek penelitian (Arikunto, 2006:130). Populasi dalam penelitian ini adalah laporan keuangan PT. Unilever Indonesia Tbk. Sedangkan sampel adalah sebagian atau wakil populasi yang diteliti (Arikunto, 2006:131). Pengambilan sampel dalam penelitian ini menggunakan metode purposive sample, dengan kriteria-kriteria kebutuhan penelitian, seperti:

1. Merger Unilever dengan Knorr dilakukan pada tahun 2004. Penelitian dilakukan selama empat tahun sebelum merger dan empat tahun sesudah merger.

2. Ketersediaan data-data yang diperlukan dalam penelitian.

Berdasarkan kriteria tersebut, maka sampel dalam penelitian ini adalah laporan keuangan PT. Unilever tahun 2000-2003 dan tahun 2005-2008.

\section{Teknik Analisis Data}

Pada penelitian ini, teknik analisis data yang digunakan adalah analisis uji beda, yaitu membandingkan dan menganalisis hasil dari perhitungan kinerja keuangan PT. Unilever Indonesia Tbk sebelum dan sesudah merger.

Langkah-langkah yang dilakukan dalam analisis data adalah sebagai berikut:

1. Mengumpulkan dan mengelompokkan data.

2. Menentukan nilai EVA perusahaan masing-masing tahun. Kemudian dihitung rata-rata besarnya EVA selama empat tahun sebelum merger dan empat tahun sesudah merger.

3. Menghitung MVA untuk masing-masing tahun. Kemudian dihitung rata-rata besarnya MVA selama empat tahun sebelum merger dan empat tahun sesudah merger.

4. Menentukan hipotesis statistik.

Ho1: Tidak terdapat perbedaan kinerja keuangan sebelum dan sesudah merger dengan menggunakan metode EVA pada PT. Unilever.

Ha1: Terdapat perbedaan kinerja keuangan sebelum dan sesudah merger dengan menggunakan metode EVA pada PT. Unilever.

Ho2: Tidak terdapat perbedaan kinerja keuangan sebelum dan sesudah merger dengan menggunakan metode MVA pada PT. Unilever. 
Ha2: Terdapat perbedaan kinerja keuangan sebelum dan sesudah merger dengan menggunakan metode MVA pada PT. Unilever.

5. Melakukan uji normalitas data.

6. Melakukan uji beda.

7. Menentukan kriteria penolakan hipotesis

Kriteria pengambilan keputusan yang digunakan adalah sebagai berikut:

Ho1: Diterima jika $\alpha>0,05$

Ditolak jika $\alpha \leq 0,05$.

Ho2: Diterima jika $\alpha>0,05$

Ditolak jika $\alpha \leq 0,05$

8. Melakukan analisis dan pembahasan.

9. Menarik kesimpulan.

\section{ANALISIS DAN PEMBAHASAN}

\section{Perhitungan EVA}

Nilai Economic Value Added (EVA) Unilever sebelum dan sesudah merger, yaitu sebagai berikut: 
Tabel 1. Perhitungan EVA

\begin{tabular}{crc}
\hline Tahun & EVA & Rata-rata \\
\hline 2000 & $455,371,171,978$ & \\
2001 & $769,223,779,063$ & $756,513,394,183$ \\
2002 & $848,258,224,363$ & \\
2003 & $953,200,401,327$ & \\
2005 & $1,309,185,820,740$ & \\
2006 & $1,606,111,621,752$ & \\
2007 & $1,793,162,800,665$ & \\
2008 & $2,109,241,720,380$ & \\
\hline
\end{tabular}

Sumber: diolah

Dari perhitungan diatas, dapat disimpulkan bahwa EVA perusahaan setiap tahunnya mengalami peningkatan. EVA terendah terjadi pada tahun 2000, yaitu sebesar Rp 455.371.171.978. Sementara EVA tertinggi dicapai perusahaan pada tahun 2008, yaitu sebesar Rp 2.109.241.720.380. Persentase kenaikan EVA tiap tahunnya berkisar antara 10\%-69\%. Persentase kenaikan EVA tertinggi terjadi pada periode 2000-2001, yaitu sebesar 69\%. Sedangkan persentase peningkatan EVA sebelum dan sesudah merger adalah sebesar 125,30\%.

Nilai EVA yang positif memiliki arti bahwa telah terjadi nilai tambah ekonomi bagi perusahaan, dimana tingkat pengembalian yang dihasilkan melebihi tingkat biaya modal atau biaya yang diminta investor atas investasi yang dilakukannya. Nilai EVA Unilever setelah melakukan merger mengalami peningkatan jika dibandingkan sebelum merger. Hal ini menunjukkan bahwa perusahaan mampu mendapatkan pengembalian atas biaya modal, dan kemampuan tersebut meningkat setelah perusahaan melakukan merger. Artinya, merger yang dilakukan Unilever menghasilkan suatu sinergi dan nilai tambah bagi perusahaan (value firm). Dengan nilai EVA yang positif ini juga menunjukkan tujuan perusahaan untuk meningkatkan nilai atau value added dari modal yang telah ditanamkan pemegang saham maupun kreditur dalam operasi perusahaan dapat tercapai. Dalam perhitungan EVA tersebut, perusahaan telah memperhatikan dan memperhitungkan adanya biaya modal atas investasi yang dilakukan, khususnya investasi dalam sekuritas saham.

\section{Perhitungan Market Value Added (MVA).}

Selain diukur dengan metode EVA, kinerja Unilever dalam penelitian ini juga diukur dengan metode market value added (MVA). MVA merupakan market value dikurangi invested capital. Market value diperoleh dari perkalian jumlah saham beredar dengan harga saham perusahaan. Sedangkan invested capital merupakan penjumlahan dari hutang jangka pendek yang menanggung bunga, hutang jangka panjang, ekuitas pemegang saham dan hak minoritas. Nilai invested capital yang digunakan pada perhitungan MVA sama dengan nilai invested capital untuk perhitungan EVA. Sehingga diperoleh nilai MVA selama periode pengamatan sebagai berikut: 
Tabel 2. Perhitungan MVA

\begin{tabular}{crr}
\hline Tahun & \multicolumn{1}{c}{ MVA } & Rata-rata \\
\hline 2000 & $8,007,252,000,000$ & \\
2001 & $10,606,132,000,000$ & $13,958,858,500,000$ \\
2002 & $11,733,938,000,000$ & \\
2003 & $25,488,112,000,000$ & \\
2005 & $30,277,384,000,000$ & \\
2006 & $47,789,451,000,000$ & \\
2007 & $48,597,222,000,000$ & $45,691,108,000,000$ \\
2008 & $56,100,375,000,000$ & \\
\hline
\end{tabular}

Sumber: diolah

Dari tabel 2 diatas diketahui bahwa nilai MVA Unilever selama periode pengamatan semuanya positif, artinya perusahaan telah berhasil menciptakan kekayaan untuk pemegang sahamnya. Semakin tinggi nilai MVA, berarti semakin baik pekerjaan yang telah dilkukan oleh para manajer bagi pemegang saham perusahaan. Nilai MVA perusahaan mengalami peningkatan setiap tahunnya. MVA terendah terjadi pada tahun 2000, yaitu sebesar Rp 8,007,252,000,000. dan MVA tertinggi terjadi pada tahun 2008, yaitu sebesar Rp 56,100,375,000,000. MVA Unilever sesudah merger mengalami peningkatan sebesar $227,33 \%$. Artinya kekayaan yang diciptakan perusahaan untuk pemegang saham mengalami peningkatan setelah merger.

\section{Hasil Pengujian Hipotesis}

Pengujian hipotesis pada penelitian ini menggunakan alat uji one sample kolmogorov smirnov. Berdasarkan hasil pengujian normalitas data dengan menggunakan perangkat lunak SPSS Versi 16.00 dengan menggunakan alat uji one sample kolmogorov smirnov diperoleh hasil sebagai berikut:

Tabel 3. Uji Normalitas MVA

One-Sample Kolmogorov-Smirnov Test

\begin{tabular}{llrr}
\hline & & Sebelum & \multicolumn{1}{c}{ Sesudah } \\
\hline $\mathrm{N}$ & & 4 & 4 \\
Normal Parameters $^{\mathrm{a}}$ & Mean & $7.57 \mathrm{E} 11$ & $1.70 \mathrm{E} 12$ \\
& Std. Deviation & $2.144 \mathrm{E} 11$ & $3.355 \mathrm{E} 11$ \\
Most Extreme Differences & Absolute & .274 & .146 \\
& Positive & .180 & .146 \\
& Negative & -.274 & -.136 \\
Kolmogorov-Smirnov Z & & .547 & .291 \\
Asymp. Sig. (2-tailed) & & .926 & 1.000 \\
\hline
\end{tabular}

a. Test distribution is Normal. 
Tabel 4. Uji Normalitas MVA

One-Sample Kolmogorov-Smirnov Test

\begin{tabular}{llrr}
\hline & & \multicolumn{1}{c}{ Sebelum } & \multicolumn{1}{c}{ Sesudah } \\
\hline $\mathrm{N}$ Normal Parameters & & 4 & 4 \\
& & $1.40 \mathrm{E} 13$ & $4.57 \mathrm{E} 13$ \\
& Mean & $7.843 \mathrm{E} 12$ & $1.094 \mathrm{E} 13$ \\
Most Extreme Differences & Std. Deviation & .362 & .326 \\
& Absolute & .362 & .171 \\
& Positive & -.224 & -.326 \\
& Negative & .723 & .652 \\
Kolmogorov-Smirnov Z & & .672 & .789 \\
Asymp. Sig. (2-tailed) & & & \\
\hline
\end{tabular}

a. Test distribution is Normal.

Dari hasil uji normalitas dengan alat uji Kolmogorov Smirnov tersebut dapat diketahui bahwa data nilai EVA dan MVA berdistribusi normal, karena nilai signifikansi kolmogorov smirnov untuk data EVA dan MVA lebih besar dari $\alpha=0,05$.

Berdasarkan hasil pengujian normalitas data dengan menggunakan perangkat lunak SPSS Versi 16.00 dengan menggunakan alat uji one sample kolmogorov smirnov menunjukkan bahwa data EVA dan MVA berdistribusi normal. Maka untuk pengujian berikutnya digunakan alat uji parametik, yaitu paired sample T-Test dengan ringkasan hasil sebagai berikut:

Tabel 5. Uji Paired Sample T-Test EVA

\begin{tabular}{|c|c|c|c|c|c|c|c|c|c|}
\hline & \multicolumn{5}{|c|}{ Paired Differences } & \multirow[b]{3}{*}{$\mathrm{t}$} & \multirow[b]{3}{*}{$\mathrm{df}$} & \multirow[b]{3}{*}{ Sig. (2-tailed) } \\
\hline & & \multirow[b]{2}{*}{ Mean } & \multicolumn{4}{|c|}{$\begin{array}{l}\text { 95\% Confidence Interval } \\
\text { of the Difference }\end{array}$} & & & \\
\hline & & & Deviation & Std. Error Mean & Lower & Upper & & & \\
\hline Pair 1 & $\begin{array}{l}\text { Sebelum - } \\
\text { Sesudah }\end{array}$ & $-9.479 \mathrm{E} 11$ & $1.466 \mathrm{E} 11$ & 7.332E10 & $-1.181 \mathrm{E} 12$ & $-7.146 \mathrm{E} 11$ & -12.929 & 3 & .001 \\
\hline
\end{tabular}

Tabel 6. Uji Paired Sample T-Test MVA

Paired Samples Test

\begin{tabular}{|c|c|c|c|c|c|c|c|c|c|}
\hline \multicolumn{10}{|c|}{ Paired Samples Test } \\
\hline & & \multicolumn{5}{|c|}{ Paired Differences } & & & \\
\hline & & & & & $\begin{array}{l}95 \% \text { Confid } \\
\text { of the D }\end{array}$ & $\begin{array}{l}\text { ce Interval } \\
\text { erence }\end{array}$ & & & \\
\hline \multirow[b]{2}{*}{ Pair 1} & & Mean & Std. Deviation & Std. Error Mean & Lower & Upper & & df & Sig. (2-tailed) \\
\hline & $\begin{array}{l}\text { Sebelum - } \\
\text { Sesudah }\end{array}$ & $-3.173 \mathrm{E} 13$ & $6.996 \mathrm{E} 12$ & $3.498 \mathrm{E} 12$ & $-4.286 \mathrm{E} 13$ & $-2.060 \mathrm{E} 13$ & -9.072 & 3 & .003 \\
\hline
\end{tabular}

Tabel Uji Paired Sample T-Test EVA diatas menunjukkan bahwa besarnya t hitung adalah 12.929 dengan derajat kebebasan 3. Otput SPSS memberikan nilai signifikansi 2-tailed $=0.001$. Nilai ini lebih kecil dari $\alpha=0.05$ maka Hol ditolak, dan Hal diterima, maka terdapat perbedaan kinerja keuangan sebelum dan sesudah merger dengan menggunakan metode EVA. 
Sedangkan uji Paired Sample T-Test MVA diatas menunjukkan bahwa besarnya t hitung adalah 9.072 dengan derajat kebebasan 3. Output SPSS memberikan nilai signifikansi 2-tailed $=$ 0.003. Nilai ini lebih kecil dari $\alpha=0.05$, maka Ho2 ditolak, dan Ha2 diterima, maka terdapat perbedaan kinerja keuangan sebelum dan sesudah merger dengan menggunakan metode MVA.

\section{Pembahasan}

Unilever merupakan perusahaan consumer goods di Indonesia dengan 400 distributor dan 500.000 outlet retailer. Perusahaan ini memiliki banyak produk yang tergolong dalam empat kategori, yaitu masakan dan makanan (seperti sariwangi, dan Royco), hidup sehat (seperti pepsodent), kecantikan dan gaya (seperti rexona, lux dan sunsilk), dan kategori rumah tangga (seperti surf dan domestos). Pada tanggal 30 Juli 2004, perusahaan melakukan merger dengan PT. Knorr Indonesia (PT. KI), produsen bumbu masak, saus, selai, minuman, dan makanan kemasan cepat saji.

Tujuan Unilever melakukan merger adalah untuk memperoleh sinergi, dan dengan memanfaatkan kapabilitas distribusi Unilever, merger ini diharapkan akan lebih mengembangkan merek-merek yang dimilikinya. Tujuan merger Unilever ini sesuai dengan teori yang dikemukakan oleh Brigham dan Gapenski (1996), bahwa perusahaan melakukan merger untuk memperoleh manfaat sinergi sebagai akibat dari penggabungan dua atau lebih perusahaan. Keuntungan yang didapat dari sinergi yakni perusahaan dapat berkembang dari berbagai macam sumber daya yang ada pada kedua perusahaan tersebut.

Selain itu, merger dilakukan untuk meningkatkan pangsa pasar (market share), karena Unilever juga merupakan produsen makanan, sama seperti PT. KI, walaupun hanya terbatas pada makanan yang berinti susu, es krim, dan minuman dengan bahan pokok teh. Bagi PT KI sendiri, merger ini bertujuan untuk menyelamatkan kondisi keuangan PT. KI yang hingga akhir tahun 2003, PT. KI sudah mencatatkan kerugian hingga Rp 10 miliar (Hermawan, Purwanto,dan Sanyoto, 2009:3).

Berdasarkan deskripsi hasil penelitian dan uji beda yang dilakukan, menunjukkan bahwa EVA selama periode penelitian bernilai positif serta terdapat perbedaan kinerja keuangan sebelum dan sesudah merger. Perbedaan ini ditunjukkan dengan adanya peningkatan nilai EVA. Hasil deskripsi penelitian dan uji beda ini didukung dengan diterimanya pengahargaan oleh Unilever untuk kategori Perusahaan dengan Keuangan Terbaik berdasarkan economic value added (EVA) pada tahun 2007 (Rm-expose.com, 2007:1).

Sesudah merger, EVA perusahaan mengalami peningkatan sebesar $125,30 \%$. Peningkatan kinerja keuangan yang tercermin dari nilai EVA Unilever sesudah merger ini disebabkan oleh naiknya laba sebelum pajak (EBIT) perusahaan setelah merger, yang berdampak langsung pada peningkatan NOPAT perusahaan sesudah merger. Selain itu peningkatan EVA ini juga dipengaruhi oleh penurunan capital charges yang merupakan tingkat pengembalian minimum yang diharapkan oleh investor (kreditur dan pemegang saham) Unilever sesudah melakukan merger.

Invested capital Unilever setelah merger mengalami peningkatan sebesar 45,40\% jika dibandingkan dengan sebelum merger, artinya kepercayaan para investor atas kemampuan Unilever mengelola investasinya mengalami peningkatan sesudah perusahaan melakukan merger.

Sedangkan WACC perusahaan sesudah merger mengalami penurunan sebanyak $51 \%$. Artinya, setelah perusahaan melakukan merger, tingkat pengembalian yang dikehendaki investor karena adanya ketidakpastian tingkat laba mengalami penurunan sebesar $51 \%$. 
Adanya perbedaan kinerja keuangan yang tercermin melalui peningkatan EVA, menunjukkan bahwa merger yang dilakukan perusahaan dapat dikatakan berhasil dan menghasilkan nilai tambah ekonomi yang lebih tinggi dibanding dengan sebelum perusahaan melakukan merger. Keberhasilan perusahaan melakukan merger ini disebabkan oleh berbagai faktor, antara lain melakukan merger yang bersahabat dengan PT. Knorr Indonesia, melakukan audit sebelum merger, serta perusahaan target mempunyai kekuatan bisnis yang cukup menguntungkan bagi Unilever, yaitu memiliki merek/produk yang sudah terkenal baik di wilayah Indonesia maupun internasional.

Hasil penelitian ini sesuai dengan teori Moin (2007), yang menyatakan bahwa setelah melakukan merger, ukuran perusahaan akan bertambah besar karena aset, kewajiban dan ekuitas perusahaan digabung bersama. Dengan bertambahnya ukuran dan ditambah dengan sinergi yang dihasilkan dari gabungan aktivitas-aktivitas simultan, maka secara logis laba perusahaan juga akan meningkat. Oleh karena itu, kinerja keuangan perusahaan sesudah merger seharusnya semakin baik dibandingkan dengan sebelum merger.

Penelitian ini mendukung penelitian yang dilakukan Fisnia (2009), dan penelitian Poposki (2007) yang menyatakan bahwa merger dapat meningkatkan kinerja perusahaan. Tetapi, merger yang dilakukan Unilever ini bertolak belakang dengan hasil penelitian Samosir dan Viverita yang menyatakan bahwa merger tidak mampu meningkatkan kinerja perusahaan.

Selain diukur dengan menggunakan metode EVA, dalam penelitian ini, kinerja keuangan Unilever sebelum dan sesudah merger juga diukur dengan menggunakan metode market value added (MVA). MVA merupakan selisih antara nilai pasar dengan modal yang diinvestasikan. Berdasarkan deskripsi hasil penelitian dan uji statistik yang dilakukan, menunjukkan bahwa terdapat perbedaan yang berupa peningkatan antara kinerja keuangan yang diukur dengan metode MVA antara sebelum dan sesudah perusahaan melakukan merger. Peningkatan ini ditunjukkan dengan peningkatan MVA sebelum dan sesudah merger sebesar 227,33\%.

Dari peningkatan MVA sebelum dan sesudah merger ini dapat dikatakan bahwa persepsi pasar (para investor) terhadap kemampuan manajemen setelah perusahaan melakukan merger mengalami peningkatan. Peningkatan MVA ini merupakan indikasi dari kemampuan manajemen untuk mengoptimalkan aset yang ditanamkan oleh para investor. Dan merger dengan PT. KI ini merupakan salah satu proyek yang dapat menciptakan, bahkan menambah kekayaan untuk pemegang sahamnya.

Peningkatan nilai MVA Unilever lebih disebabkan oleh market value perusahaan, yang tercermin dari harga saham dan jumlah saham beredarnya, walaupun tidak terlepas dari modal yang diinvestasikan pada perusahaan.

Ekspektasi yang positif dari para investor juga ditunjukkan dengan meningkatnya modal yang diinvestasikan pada perusahaan, antara sebelum dan sesudah merger. Modal yang diinvestasikan sebelum merger sebesar Rp 1.930.616.500.000, dan meningkat sebesar 45,40\% menjadi Rp 2.807.079.500.000. Modal diinvestasikan (invested capital) ini menjadi komponen pengurang market value dalam pengukuran kinerja dengan metode MVA. Nilai MVA yang selalu positif menunjukkan bahwa nilai invested capital perusahaan tidak lebih besar dari nilai pasarnya.

Kinerja keuangan Unilever, baik yang diukur secara internal melalui EVA, maupun dari indikator eksternal yang berupa market value added, mengalami perbedaan yang berupa peningkatan antara sebelum dan sesudah merger.

Hasil penelitian ini sesuai dengan teori Moin (2007), yang menyatakan bahwa setelah melakukan merger, seharusnya kinerja keuangan perusahaan semakin baik, artinya terdapat 
peningkatan kinerja. Peningkatan ini ditandai dengan meningkatnya nilai MVA Unilever sesudah merger.

\section{KESIMPULAN DAN SARAN \\ Kesimpulan}

Dari hasil analisis dan pembahasan yang telah dilakukan, dapat disimpulkan beberapa hal, yaitu sebagai berikut:

1. Kinerja keuangan Unilever yang diukur dengan menggunakan metode EVA menunjukkan bahwa terdapat perbedaan kinerja yang berupa peningkatan nilai EVA sebelum dan sesudah merger. Perbedaan ini disebabkan oleh peningkatan NOPAT, serta penurunan capital charges sesudah perusahaan melakukan merger. Peningkatan EVA ini menunjukkan bahwa perusahaan mampu memperoleh sinergi dari merger yang dilakukannya.

2. Kinerja keuangan Unilever jika diukur dengan menggunakan metode MVA juga menunjukkan hasil yang sama, yaitu terdapat perbedaan kinerja yang berupa peningkatan. Peningkatan nilai MVA Unilever lebih disebabkan oleh market value perusahaan, yang tercermin dari harga saham dan jumlah saham beredarnya, walaupun tidak terlepas dari modal yang diinvestasikan pada perusahaan. Dengan demikian dapat disimpulkan bahwa kinerja keuangan Unilever, baik yang diukur secara internal melalui EVA, maupun dari indikator eksternal yang berupa market value added, mengalami perbedaan yang berupa peningkatan antara sebelum dan sesudah merger.

\section{Saran}

1. Bagi investor.

PT Unilever Indonesia Tbk dapat menjadi salah satu alternatif investasi yang menguntungkan bagi para investor saham. Kinerja keuangan Unilever yang selalu meningkat disetiap tahun, baik dinilai dari nilai tambah ekonomi maupun dari nilai tambah pasarnya, dapat menjadi salah satu acuan bagi para investor saham untuk menginvestasikan modalnya pada PT Unilever Indonesia Tbk.

2. Bagi perusahaan.

Meskipun nilai perusahaan tidak hanya dipengaruhi oleh kinerja keuangan, perusahaan tetap perlu memperhatikan, bahkan meningkatkan kinerja keuangannya karena kinerja keuangan tetap memiliki pengaruh terhadap harga saham. Selain itu, kinerja keuangan yang meningkat juga akan meningkatkan nilai perusahaan tersebut dimata investor. Sehingga peluang perusahaan memperoleh dana dari investor akan semakin besar, dan perusahaan dapat memperoleh kemudahan untuk menjalin kerjasama dengan pihak-pihak diluar perusahaan Jadi, untuk dapat mempertahankan dan meningkatkan kinerja keuangannya, sebaiknya perusahaan menginvestasikan dananya pada proyek-proyek atau bisnis yang dapat menciptakan keuntungan dan nilai tambah bagi perusahaan.

3. Bagi penelitian selanjutnya.

Penelitian ini hanya menganalisis kinerja perusahaan pada aspek keuangannya saja, padahal masih banyak faktor lagi yang perlu diperhatikan seperti faktor sumber daya manusia, pelayanan, budaya perusahaan, dan lain-lain. Sehingga pada penelitian berikutnya diharapkan aspek-aspek lain juga ikut dianalisis untuk mendapatkan hasil yang lebih akurat. Selain itu, pada penelitian selanjutnya dapat menggunakan alat ukur kinerja lain diluar EVA dan MVA. Misalnya dengan menggunakan alat ukur Financial Value Added (FVA). 


\section{DAFTAR PUSTAKA}

Brigham, Eugene F dan Louis C. Gapenski. 1996. Intermediate Financial Management. Fifth Edition. The Dryden press: Florida.

Brigham, Eugene F dan Joel F. Houston. 2006. Dasar-dasar Manajemen Keuangan. Buku 1 dan 2. Edisi kesepuluh. Jakarta: Salemba Empat

Campaka, Michelia. 2009. Analisis EVA (Economic value added) dalam pengukuran kinerja keuangan serta hubungannya dengan MVA (market value added) pada perusahaan food and beverages yang Go Public di BEI. Skripsi tidak diterbitkan. Surabaya: FE UNESA.

Fisnia, Dewi. 2009. Analisis EVA (Economic value added) untuk mengukur kinerja keuangan perusahaan yang Go Public di BEI sebelum dan sesudah merger. Skripsi tidak diterbitkan. Surabaya: FE UNESA.

Hermawan, hardy dkk. 2009. Santapan Empuk Bagi Unilever. (Online). (http:// www.majalahtrust.com, diakses tanggal 2 februari 2010)

Husnan, Suad. 1998. Dasar-dasar Teori Portfolio dan Analisis Sekuritas. Edisi Ketiga. Yogyakarta: UPP AMP YKPN.

Husnan, Suad dan Enny Pudjiastuti. 2004. Dasar-dasar Manajemen Keuangan. Edisi Keempat. Yogyakarta: UPP AMP YKPN.

Iramani, Rr dan Febrian, Erie. 2005. Financial Value Added: Suatu Paradigma dalam Pengukuran Kinerja dan Nilai tambah Perusahaan. Jurnal Akuntansi Keuangan, (online), Vol. 7 No. 1, Mei 2005: 1-10, (http/www.untoro.staff.gunadarma.ac.id, diakses tanggal 17 November 2009)

Jogiyanto, H. M. 2003. Teori Portfolio dan Analisis Investasi. Yogyakarta: BPFE.

Moin, Abdul. 2007. Merger, Akuisisi dan Divestasi Jilid 1. Yogyakarta: Ekonisia.

Mulyadi. 2001. Akuntansi Manajemen: Konsep, Manfaat, dan Rekayasa. Edisi 2. Yogyakarta: Bagian penerbitan STIE YKPN.

Poposki, Klime. 2007. Merger Activity in the Insurance Industry. Economics and Organization, (online), Vol. 4, No. 2, 2007:161-171, (http://www.sciendirect.com, diakses tanggal 2 Maret 2010).

Rm-expose. 2010. Penjualan Unilever Naik Menjadi Rp 11,3 T. (online). (http://www.rmexpose.com, diakses tanggal 6 Juni 2010).

Samosir, Agunan P. 2003. Analisis Kinerja Bank Mandiri Setelah Merger dan Sebagai Bank Rekapitalisasi. Kajian Ekonomi dan Keuangan, (online), Vol. 7, No.1 Maret 2003, (http//:www.fiskal.depkeu.go.id, diakses 17 November 2009).

Utomo, Lisa linawati. 1999. Economic Value Added sebagai ukuran keberhasilan kinerja manajemen perusahaan. Jurnal akuntansi dan keuangan. (online), Vol. 1, No.1, Mei 1999: 28-42, (http://puslit2.petra.ac.id, diakses tanggal 6 Maret 2010.

Viverita. Tanpa tahun. The Effect of Mergers on Bank Performance: Evidence From Bank Consolidation Policy In Indonesia. (online). (http://www.wbiconpro.com, diakses tanggal 7 Oktober 2009)

Wet, de dan Hall. 2004. The relationship between EVA, MVA and leverage. Meditari Accountacy Research. (online). Vol. 12, No.1. 2004: 39-59, (http://www.emeraldinsight.com, diakses tanggal 2 Maret 2010).

Young, David dan O'Byrne, Stephen. 2001. EVA dan Manajemen Berdasarkan Nilai Panduan Praktis Untuk Implementasi. Terjemahan oleh Lusi Wijaya. Jakarta: Salemba Empat. 
Zafiris dan Bayldon. 1999. Economic Value Added and Market Value Added: a Simple Version and Application. Journal of Applied Accounting Research, (online), Vol. 5, Issue II, Desember 1999, (http://www.emerald insight.com, diakses tanggal 2 Maret 2010). 